\title{
Soil organic carbon and nitrogen pools as influenced by polyphenols in different particle size fractions under tropical conditions
}

\author{
G. Seneviratne ${ }^{1^{*}}$, M.P.N.K. Henakaarchchi ${ }^{2}$, M.L.M.A.W. Weerasekara ${ }^{2}$ and K.A. Nandasena ${ }^{2}$ \\ ${ }^{l}$ Institute of Fundamental Studies, Hantana Road, Kandy. \\ 2 Department of Soil Science, Faculty of Agriculture, University of Peradeniya, Peradeniya.
}

Revised: 11 August 2008 ; Accepted: 02 October 2008

\begin{abstract}
Soil organic carbon (SOC) and nitrogen (N) pools are highly dependent on physico-chemical quality and composition of plant litter. Polyphenols are widely spread in the plant kingdom and found in plant litter. They are known to affect the chemical and biological processes in the soil. The objective of this study was to examine the effects of polyphenols on the soil organic matter (SOM) pools in different particle size fractions under tropical conditions. Soils were collected from 19 different sites in wet, dry and intermediate zones of Sri Lanka. The bulk soil was fractionated into three particle size fractions (coarse sand, 2-0.25 mm; fine sand, 0.25-0.05 mm; clay + silt,$<0.05 \mathrm{~mm}$ ) by dry sieving. Total SOC, total $\mathrm{N}$, labile SOC and polyphenol contents were determined in each fraction. The SOC and $\mathrm{N}$ pools were mainly associated with clay + silt fraction. More correlations between the variables were present in clay + silt and fine sand fractions than the coarse sand fraction. Labile SOC decreased with the increase of polyphenol/ $\mathrm{N}$ ratio in the clay + silt fraction, suggesting the presence of a negative response of polyphenols on microbial growth. Labile SOC, total N and stable SOC increased with polyphenols in fine sand and clay + silt fractions, which indicates a positive response of polyphenols on $\mathrm{C}$ sequestration and $\mathrm{N}$ accumulation owing to reduced decomposition and chemical immobilization, respectively. However, further studies are necessary to investigate the role played by polyphenols on the SOM decomposition and nutrient cycling of tropics.
\end{abstract}

Keywords: Labile carbon, organic carbon, polyphenols, stable carbon, total nitrogen, tropical soils.

\section{INTRODUCTION}

Plant litter decomposition plays a key role in nutrient cycling, determining the productivity of natural and agroecosystems. It mainly depends on physico-chemical quality of the litter as well as environmental factors ${ }^{1}$ and determines the qualities of the SOC and $\mathrm{N}$ pools ${ }^{2}$.

Polyphenolic compounds are widespread in the plant kingdom and are the most abundant group of plant phenolic compounds with known antioxidant properties ${ }^{3}$. They are relatively resistant to microbial degradation and control many aspects of plant-microbial interactions by increasing or decreasing microbial activity ${ }^{4}$. Many negative feedbacks of polyphenols have been identified whereby plants degrade fertile soils through the production of polyphenol rich litter ${ }^{5,6}$. Polyphenols convert soil nutrients into unavailable forms, inducing toxicities to microbial population, inhibiting enzyme activities and creating unfavourable condition for seed germination, root growth and nutrient uptake ${ }^{7}$.

However, there are many positive feedbacks of polyphenols reported elsewhere ${ }^{8-10}$. By inhibiting decomposition, polyphenols regulate the formation of humus layer, conserving sequestrated carbon and nutrients, creating a more favourable medium for root growth, and complexing $\mathrm{Al}, \mathrm{Mn}$ and $\mathrm{Fe}$ by chelation which reduces potential toxicities such as Al toxicity and $\mathrm{P}$ fixation in the soil ${ }^{7}$.

Most of the experimental studies on plant litter quality defined chemical quality indices using various ratios of $\mathrm{C}, \mathrm{N}$ and polyphenols ${ }^{2}$, and have attempted to predict the litter decomposition and nutrient release $\mathrm{e}^{1,8,11}$. However, the role played by polyphenols on the organic matter pools has been under-studied, except for a few temperate studies mentioned above. Further, the quality 
and quantity of the SOM pools vary with the particle size fractions of the soils ${ }^{12}$, and the fractionation allows a better understanding of the SOM rather than unfractionated soil $^{13}$. Thus the objective of the present study was to examine the effect of the soil polyphenols on the SOC and $\mathrm{N}$ pools of different particle size fractions in some tropical soils.

\section{METHODS AND MATERIALS}

Site selection, soil sampling and sample preparation: Sri Lanka has a tropical climate and is divided into wet, intermediate and dry zones based on the intensity of rainfall ${ }^{14}$. Soil samples were collected from 16 home gardens, 2 vegetable fields and a cocoa plantation representing a range of soils in dry, wet and intermediate zones. The floor litter layer was removed and three random soil samples were taken from a $0-10 \mathrm{~cm}$ depth from each site to prepare a composite sample. The samples were air dried at room temperature and all visible organic debris, living fauna, stones, plant roots etc., were removed. Soil fractionation was done by the dry sieving method. Three hundred and fifty grams of the soil samples were fractionated to $2-0.25 \mathrm{~mm}, 0.25-0.05 \mathrm{~mm}$ and $<0.05 \mathrm{~mm}$ using a mechanical sieve shaker. They represented coarse sand, fine sand and clay + silt fraction, respectively.

Chemical Analyses: Soil $\mathrm{pH}$ was measured at a ratio of 1:2.5 (w/w) of soil to water, using a $\mathrm{pH}$ meter. Total extractable polyphenols was measured by Folin-Denis reagent ${ }^{15}$. Labile SOC (microbial biomass $\mathrm{C}$ and other easily decomposable $\mathrm{C}$ ) was measured by the modified permanganate oxidizable $\mathrm{C}$ method $^{16}$. Total SOC was determined by the wet oxidation method without using external heating, in which organic carbon was oxidized by the acidified dichromate solution ${ }^{15}$. Then, stable SOC was calculated by subtracting the labile SOC from the total SOC. Total $\mathrm{N}$ was analyzed using the Kjeldhal $\operatorname{method}^{17}$. Data were analyzed using the Proc GLM procedure and means were separated by Tukey's HSD test. Correlation and regression analyses were performed

Table 1: Initial soil properties of the sites studied

\begin{tabular}{lccc}
\hline Soil character & Range & Mean & CV (\%) \\
\hline $\mathrm{pH}$ & $4.20-8.33$ & 6.45 & 16.39 \\
Polyphenols $(\mathrm{g} / 100 \mathrm{~g})$ & $2.14-6.99$ & 4.20 & 27.73 \\
Labile C $(\mathrm{g} / 100 \mathrm{~g})$ & $0.23-1.89$ & 0.98 & 60.20 \\
Stable C (g/100 g) & $1.01-4.77$ & 2.35 & 43.01 \\
Total C (g/100 g) & $1.44-5.63$ & 3.33 & 39.23 \\
Total N (g/100 g) & $0.025-0.15$ & 0.062 & 50.26 \\
\hline
\end{tabular}

$\mathrm{CV}$ - coefficient of variation to establish relationships. All data were analysed using SAS software ${ }^{18}$.

\section{RESULTS AND DISCUSSION}

Soil $\mathrm{pH}$ varied from 4.20 to 8.33 in different sites sampled (Table 1). Labile $\mathrm{C}$ and total $\mathrm{N}$ showed very high variabilities whereas stable $\mathrm{C}$ had a relatively low variability among sites. The SOC and $\mathrm{N}$ pools among the three particle size fractions increased in the order of: coarse sand $<$ fine sand $<$ clay + silt $($ Table 2$)$. Their calculated $\mathrm{C} / \mathrm{N}$ ratios increased in the order of: coarse sand $=$ clay + silt $<$ fine sand. Those pools were highly associated with the clay + silt fraction than the other two fractions. Similar results have been reported by many researchers ${ }^{19-21}$. In general, sand sized fractions mainly consist of macro-organic matter which are much susceptible to microbial mineralization. On the other hand, clay and silt sized particles are enriched in microbial products and plant derived aromatic compounds, which are inaccessible to microbes. Therefore, the SOM is preserved in the fine fractions as the primary reservoir of $\mathrm{C}$ and $\mathrm{N}^{22,23}$.

A negative relationship was observed between the labile SOC and polypheno01/N ratio in clay + silt fraction (Figure 1). Many studies have shown that polyphenols decrease the $\mathrm{N}$ availability ${ }^{8,24,25,26}$. It has been reported that the polyphenol/ $\mathrm{N}$ ratio is a determinant of the $\mathrm{N}$ release of organic materials with limited $\mathrm{N}$ concentrations $<1 \%{ }^{26}$. In agreement with that, present study indicated that the relationship was significant when soil total $\mathrm{N}$ concentrations were $<0.42 \%$. In both studies, the $\mathrm{C} / \mathrm{N}$ ratios of the substrates were comparable (i.e. 31 against 37). Phenolic compounds have been shown to increase $\mathrm{N}$ immobilization through protein complexation, thus decreasing the $\mathrm{N}$ availability for microbial growth ${ }^{27}$. This was confirmed by the observed positive correlation between polyphenols and total $\mathrm{N}$ in both fine sand and clay + silt fractions (Table 3 ). This process enhances $\mathrm{N}$

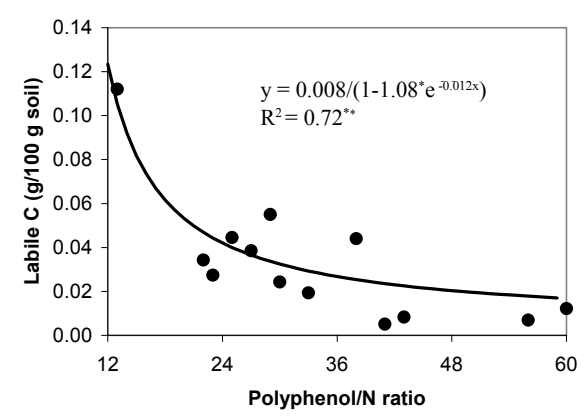

Figure 1: Relationship between labile SOC and polyphenol/ $\mathrm{N}$ ratio in clay + silt fraction of the soils studied 
Table 2: Distribution of organic carbon and nitrogen pools in different particle size fractions of the soils studied

\begin{tabular}{lccccc}
\hline & Polyphenol & Labile C & Total SOC & Total N & $\begin{array}{c}\text { Polyphenol/N } \\
\text { ratio }\end{array}$ \\
\cline { 2 - 5 } & \multicolumn{5}{c}{$(\mathrm{g} / 100 \mathrm{~g}$ soil $)$} \\
Coarse sand & $6.00 \mathrm{a}$ & $0.1259 \mathrm{~b}$ & $2.86 \mathrm{~b}$ & $0.078 \mathrm{~b}$ & $116 \mathrm{a}$ \\
Fine sand & $4.32 \mathrm{~b}$ & $0.1562 \mathrm{~b}$ & $4.27 \mathrm{~b}$ & $0.111 \mathrm{~b}$ & $49.1 \mathrm{~b}$ \\
Clay + silt & $5.38 \mathrm{ab}$ & $0.2277 \mathrm{a}$ & $7.34 \mathrm{a}$ & $0.202 \mathrm{a}$ & $32.7 \mathrm{~b}$ \\
MSD (0.05) & 1.06 & 0.0564 & 2.58 & 0.042 & 43.7 \\
CV (\%) & 25.5 & 41.8 & 67.4 & 40.5 & 83.4 \\
\hline
\end{tabular}

Values in the same column followed by different letters are significantly different at $5 \%$ probability level. MSD-minimum significant difference. CV-coefficient of variation.

Table 3: Correlation coefficients ( $\mathrm{r}$ ) between the soil organic carbon and nitrogen pools of different particle size fractions of the soils studied

\begin{tabular}{llccc}
\hline & & Labile C & Stable C & Total N \\
\hline \multirow{2}{*}{ Polyphenol } & Coarse sand & $0.040 \mathrm{~ns}$ & $-0.198 \mathrm{~ns}$ & $-0.319 \mathrm{~ns}$ \\
& Fine sand & $0.601 * *$ & $0.480 *$ & $0.414 \mathrm{~ns}$ \\
& Clay + silt & $0.734 * *$ & $0.446 \mathrm{~ns}$ & $0.614^{* *}$ \\
\multirow{3}{*}{ Labile C } & Coarse sand & - & $0.294 \mathrm{~ns}$ & $-0.039 \mathrm{~ns}$ \\
& Fine sand & - & $0.729 * *$ & $0.748 * *$ \\
& Clay + silt & - & $0.332 \mathrm{~ns}$ & $0.845^{* *}$ \\
Stable C & Coarse sand & - & - & $0.629 * *$ \\
& Fine sand & - & - & $0.935 * *$ \\
& Clay + silt & - & - & $0.391 \mathrm{~ns}$ \\
\hline
\end{tabular}

ns- not significant at $5 \%$ probability level.

* significant at $5 \%$ probability level.

** highly significant (probability $<1 \%$ ).

conservation and sequestration into a large unavailable pool of the $\mathrm{SOM}^{7,28}$. Consequently, it decreases microbial biomass $\mathrm{C}$ in the soil, which is positively correlated with the labile $\mathrm{C}$ content $^{29,30}$. In addition, polyphenols may interfere in enzyme functions or decomposer metabolism, resulting in the reduction in microbial growth ${ }^{31}$.

In the fine sand and clay + silt fractions, there were positive correlations between polyphenols and labile SOC. This could be due to degradation and use of polyphenols as food sources by laccase producing microbes $^{32}$. It has been reported that phenolics primarily increase microbial activity when biota use phenolic compounds as a $\mathrm{C}$ source ${ }^{9,10}$. On the other hand, some fungi can produce polyphenolic compounds as secondary metabolites. Consequently, polyphenol content increases with polyphenol-producing fungal population ${ }^{8}$, which contributes to labile SOC pool. The labile SOC content was positively correlated with the total $\mathrm{N}$ content in clay + silt and fine sand fractions, indicating the immobilization of $\mathrm{N}$ in the microbial biomass (Table 3 ).
This study indicates that polyphenols play a role in controlling $\mathrm{N}$ availability and labile SOC and hence stable $\mathrm{C}$ accumulation in the fine soil fractions, but it is not clear in the coarse fraction. The fractionation of the soils revealed that, this control occurs in the fine fractions, which would otherwise be masked by the coarse fraction. Thus, it is clear that soil polyphenols affect positively as well as negatively on the SOC and N pools not only in temperate conditions, but also in the tropics. Such effects in the coarse fraction have not been reported. On the basis of the above findings, it is necessary that further studies be carried out to investigate the role played by polyphenols on the SOM decomposition and nutrient cycling in the tropics.

\section{Acknowledgement}

The assistance rendered by Ms. K. Karunaratne, Dr. R. Ratnayake, and Mr. K. Karunadasa and all other members of the BNF project is acknowledged for their valuable support during this study. Resources generated through funding of the Belgian Administration for the Development Corporation (BADC) during 1991-1997 were also used in the present study.

\section{References}

1. Seneviratne G. (2000). Litter nitrogen release in tropical agro-ecosystems. Current Science 79(8): 1054.

2. Vanlauwe B., Diels J., Sanginga N. \& Merckx R. (1997). Residue quality and decomposition: an unsteady relationship? In: Driven by Nature: Plant Litter Quality and Decomposition. (Eds. G. Cadisch \& K.E. Giller). pp. 157-166. CAB, Wallingford, UK.

3. Rice-Evans C.A., Burdon R.H. \& Binding R.H. (1994). Free Radical Damage and its Control. pp. 408. Elsevier, Amsterdam.

4. Jayasinghearachchi H.S., Seneviratne G. \& Weerasinghe H.M.P.M. (2006). Tannin interactions with legumerhizobial $\mathrm{N}_{2}$ fixing symbiosis. International Journal of Agricultural Research 1(1): 1-7. 
5. Kuiters A.T. (1990). Role of phenolic substances from decomposing forest litter in plant-soil interactions. Acta Botanica Neerlandica 39(4):329-348.

6. Chapin F. (1993). The evolutionary basis of biogeochemical soil development. Geoderma 57(3): 223-227.

7. Northup R.R., Dahlgren R.A. \& McColl J.G. (1998). Polyphenols as regulators of plant-litter-soil interactions in northern California's pygmy forest: a positive feedback? Biogeochemistry 42(1-2): 189-220.

8. Hattenschwiler S. \& Vitousek P.M. (2000). The role of polyphenols in terrestrial ecosystem nutrient cycling. Trends in Ecology and Evolution 15(6): 238-243.

9. Fierer N., Schimel J.P., Cates R.G. \& Zou J. (2001). Influence of balsam poplar tannin fractions on carbon and nitrogen dynamics in Alaskan taiga floodplain soils. Soil Biology and Biochemistry 33(12-13): 1827-1839.

10. Schimel J.P., Cates R.G. \& Ruess R. (1998). The role of balsam poplar secondary chemicals in controlling soil nutrient dynamics through succession in the Alaskan taiga. Biogeochemistry 42(1-2): 221-234.

11. Rimmera D.L. (2006). Free radicals, antioxidants, and soil organic matter recalcitrance. European Journal of Soil Science 57(2): 91-94.

12. Glasser B., Turrion M.P., Solomon D., Ni A. \& Zech W. (2000). Soil organic matter quantity and quality in mountain soils of the Alay range, Kyrgyzia affected by deforestation. Biology and Fertility of Soils 31(5): 407-413.

13. Lopez-Capel E., Sohi S.P., Gount J.L. \& Manning D.A.C. (2005). Use of thermogravimetry differential scanning calorimetry to characterize modelable soil organic matter fractions. Soil Science Society of America Journal 69(1): 136-140.

14. Dormros M. (1974). The Agroclimate of Ceylon. pp. Franz Steiner Verlag, GmbH, Wiesbaden, Germany.

15. Anderson J.M. \& Ingram J.S.I. (1993). Tropical Soil Biology and Fertility: A Handbook of Methods. CAB, Wallingford, UK.

16. Weil R.R., Islam K.R., Stine M.A., Gruver J.B. \& Samson-Liebig S.E. (2003). Estimating active carbon for soil quality assessment: a simplified method for laboratory and field use. American Journal of Alternative Agriculture 18(1): 3-17.

17. Bremner T.M. \& Tabatadai M.A. (1972). Use of an ammonia electrode for determination of ammonium in Kjeldahl analysis of soils. Communications in Soil Science and Plant Analysis 3: 159-165.

18. SAS Institute (1996). SAS/STAT User's Guide, Release 6.03., SAS Institute Inc., Cary, NC, USA.

19. Solomon D., Lehmann J. \& Zech W. (2000). Land use effects on soil organic matter properties of chromic luvisols in semi-arid northern Tanzania: carbon, nitrogen, lignin and carbohydrates. Agriculture, Ecosystems and Environment 78(3): 203-213.

20. Chantigny M.H., Angers D.A., Prevost D., Vezina L.P. \& Chalifour F.P. (1997). Soil aggregation and fungal and bacterial biomass under annual and perennial cropping systems. Soil Science Society of America Journal 61(1): 262-267.

21. Guggenberger G., Christensen B.T. \& Zech W. (1994). Land use effects on the composition of organic matter in particle-size separates of soil: I Lignin and carbohydrate signature. European Journal of Soil Science 45(4): 449458.

22. Christensen B.T. (2001). Physical fractionation of soil and structural and functional complexity in organic matter turnover. European Journal of Soil Science 52(3):345-353.

23. Martin J.P. \& Haider K. (1986). Influence of mineral colloids on turnover rates of soil organic carbon. In: Interactions of Soil Minerals with Natural Organics and Microbes. (Eds. P.M. Huang \& M. Schnitzer). pp. 283304. Soil Science Society of America, Madison, USA.

24. Horner J.D., Gosz J.R. \& Cates R.G. (1988). The role of carbon-based plant secondary metabolites in decomposition in terrestrial ecosystems. American Naturalist 132(6): 869- 883 .

25. Nicolai V. (1988). Phenolic and mineral content of leaves influences decomposition in European forest ecosystems. Oecologia 75(4): 575-579.

26. Seneviratne G. (2000). Litter quality and nitrogen release in tropical agriculture: a synthesis. Biology and Fertility of Soils 31(1): 60-64.

27. Sugai S.F. \& Schimel J.P. (1993). Decomposition and biomass incorporation of 14C-labeled glucose and phenolics in taiga forest floor: effect of substrate quality, successional state, and season. Soil Biology and Biochemistry 25(10): 1379-1389.

28. Bending D.G. \& Read D.J. (1997). Lignin and soluble phenolic degradation by ectomycorrhizal and ericoid mycorrhizal fungi. Mycological Research 101(11):13481354.

29. Paul C.L. \& Clark S.J. (1996). Cytosine methylation: quantitation by automated genomic sequencing and Genescan analysis. BioTechniques 21(1): 126-133.

30. Alvarez R. \& Alvarez C.R. (2000). Soil organic matter pools and their association with carbon mineralization kinetics. Soil Science Society of America Journal 64(1): 184-189.

31. Palm C.A. \& Sanchez P.A. (1990). Decomposition and nutrient release patterns of the leaves of three tropical legumes. Biotropica 22(4): 330-338.

32. Thurston C.F. (1994). The structure and function of fungal laccases. Microbiology 140(1): 19-26. 